\section{Dry Matter Distribution of Three Peach Growth Types}

\author{
Daniela Giovannini ${ }^{1}$, D. Michael Glenn, Ralph Scorza, and \\ W.V. Welker \\ U.S. Department of Agriculture, Agricultural Research Service, Appalachian \\ Fruit Research Station, 45 Wiltshire Road, Kearneysville, WV 25430
}

Additional index words. root growth, shoot growth

\begin{abstract}
Our objective was to evaluate the dry-matter partitioning between the roots and shoots of two genetically size-controlled peach [Prunus persica (L.) Batsch] types, dwarf and pillar, compared to a full-sized standard peach type. Compared to the pillar and standard types, the dwarf type had a reduced leaf : root ratio, less allocation of dry matter to woody tissue and more to leaf tissue. Genetically size-controlled peach trees have a smaller root system, but a lower leaf : root ratio and may require modified soil and water management techniques to ensure high productivity.
\end{abstract}

Growth habits in peach were first reported in 1867 , when a dwarf form was described (Hooper, 1867; Strong, 1867). Since then, six growth types have been identified: standard, compact, semidwarf, pillar, weeping, and spur (Scorza, 1988). A better understanding of the physiological basis of the different growth habits is important for optimal use of any peach growth type (Scorza, 1988). Some studies have attempted to identify differences in the hormonal patterns of the peach growth types (Cristoferi and Filiti, 1981; Glenn and Scorza, 1992; Scorza and Cordts, 1989; Wylie and Ryugo, 1971); however, little attention has been paid to physiological behavior of peach growth types. Relative to the standard growth types, some dwarf types 1) allocate a larger percentage of above-ground dry weight to fruit, leaves, and small branches and a smaller percentage to the larger wood component (DeJong and Doyle, 1984); 2) have higher root resistance to water flow (Glenn and Scorza, 1992); and 3) have higher leaf photosynthetic rates (Cappellini et al., 1992). These characteristics indicate an altered physiology associated with the different growth types in peach. Our objective was to evaluate the partitioning of dry matter distribution between roots and shoots of two genetically size-controlled types [dwarf (DW) and pillar (PI)] compared to a full-sized standard (ST) peach type. This information is needed to develop cultural practices for reduced-sized peach types.

Received for publication 20 Aug. 1993. Accepted for publication 29 July 1994. Reference to company name or product name does not imply approval or recommendation of the product by the U.S. Dept. of Agriculture to the exclusion of others that may be suitable. The cost of publishing this paper was defrayed in part by the payment of page charges. Under postal regulations, this paper therefore must be hereby marked advertisement solely to indicate this fact.

${ }^{1}$ Current address: Istituto Sperimentale per la Frutticoltura di Roma, Sezione di Forli, Piazzale della Vittoria, 15, Forli, Italy 47100.

\section{Materials and Methods}

DW, PI, and ST trees were budded to oneyear-old, open-pollinated seedlings of Bailey rootstocks in Fall 1990. 'Valley Red' (DW) (Hansche, 1989) is a brachytic dwarf characterized by extremely short internodes, large leaves, and narrow branch angles compared to ST trees (Scorza, 1984). The PI genotype is characterized by extremely narrow branch angles that result in an upright, columnar tree (Scorza et al., 1989). The PI genotype in this study was provided by A. Vordeckers, Rutgers Univ., New Brunswick, N.J. 'Redskin' was selected to represent the ST genotype. In Spring 1991, four trees of each genotype were moved into a greenhouse and transplanted in the middle of four-section rhizotrons filled with the ' $\mathrm{A}$ ' horizon of a Hagerstown silt loam soil (Glenn and Welker, 1991). Throughout the experiment, the trees were well watered and fertilized; pests were controlled when necessary. The design was a completely randomized block with four replications. Data were analyzed using analysis of variance (ANOVA) and Gabriel-Rinot least significant range test for mean separation. Differences in leaf and shoot development rate for the three growth types were based on a least significant difference calculated from the pooled ANOVA tested for significant differences in slope and intercept. All tests were made at $P=0.05$.

The number of new leaves per tree, the number of lateral shoots, and the branch angle from horizontal were recorded from June through October. Average leaf area and leaf dry weight were determined on samples of 20 leaves per tree, and total leaf area was estimated by multiplying the number of leaves times the average leaf area of each genotype. Specific leaf weight (gram per square centimeter) was calculated from 20 leaves per tree. Stomata per square millimeter were counted on the epidermal imprint of the leaf abaxial surface of seven leaves per genotype. For each leaf, six microscope fields were counted.

Nine $218-\mathrm{cm}^{3}$ soil cores were collected at three depths $(9,27$, and $45 \mathrm{~cm}$ from the soil surface) and positions within the same depth
$(9,27$, and $45 \mathrm{~cm}$ from the central section) in July, September, and October. A different section of the rhizotron was sampled at each sampling time. The roots were separated from the soil with an elutriation technique (Smucker et al., 1982), and the root length of fine and large roots $(>1 \mathrm{~mm}$ in diameter) were determined using Tennant's (1975) modified line intersect method. Root length density (centimeter per cubic centimeter) was calculated as root length (centimeter per $218 \mathrm{~cm}^{3}$ of soil).

At the end of the experiment, the remaining nonsampled section was removed from the rhizotrons, and a $50 \times 50-\mathrm{cm}$ square board with $15-\mathrm{cm}$-long nails spaced $5 \mathrm{~cm}$ apart was pushed into the cut soil section. The soil was gently washed out so that the frame of the root system appeared in its natural position in the soil. The main root branch angles from the vertical axis then were recorded for roots $\geq 5 \mathrm{~mm}$ in diameter.

Five to seven roots ranging from 2 to $5 \mathrm{~mm}$ in diameter $\left(\operatorname{root}_{\mathrm{w}}\right)$ were sectioned with a razor blade to determine the total root xylem width $\left(\right.$ xylem $\left._{w}\right)$; the $x_{\text {ylem }}$ : root $_{w}$ ratio was calculated based on the respective areas of the tissues. The number of vessels were counted, and the lumen of the largest vessels were measured in all sections.

After their length had been measured, samples of fine roots were oven-dried at 70C to calculate the root dry weight per unit of length (specific root length, milligram per centimeter). The fine root mass at each sampling was calculated as the product of root length, density, specific root length, and root volume $\left(13,000 \mathrm{~cm}^{3}\right)$. The root mass of roots $\geq 1 \mathrm{~mm}$ long was measured by weighing the root segments of this size category. The total leaf mass at each sampling was calculated as the product of leaf count, specific leaf weight, and leaf area. The effect of growth type and sampling date on the leaf : root mass ratio was evaluated in a split-plot design with sampling date as the main plot and growth type as the subplot.

All the leaves were stripped from the trees at the end of the experiment. A representative sample was air-dried and then analyzed for $\mathrm{N}$ content using an N analyzer (model FP228; LECO Corp., St. Joseph, Mich.). The diameter of six shoots per tree (all the shoots in the dwarf type) and the xylem diameter were measured, and the xylem : total shoot diameter ratio was calculated. All the shoots and the laterals then were separated from the main stem and dried at 70C.

\section{Results and Discussion}

Tree structure and morphology of the three peach growth types differed. Weight of the above-ground wood was highest for ST (607 $\mathrm{g} /$ tree), intermediate (183 g/tree) for PI, and lowest $(20 \mathrm{~g} /$ tree $)$ for DW. The xylem area percentage in the shoots $(76 \%)$ was slightly less for DW than for PI or ST (81\% for both). Shoot branch angle was most horizontal in ST $\left(28^{\circ}\right)$, intermediate in DW $\left(45^{\circ}\right)$, and most vertical in $\mathrm{PI}\left(58^{\circ}\right)$. These growth characteristics combined to produce a conical-shaped ST, 
a columnar-shaped PI, and a globe-shaped DW.

Leaf development was most extensive for ST and least extensive for DW (Fig. 1A). Dwarf trees ceased new shoot production in early July (about day 190) and PI in late August (about day 250), whereas ST continued to initiate new shoots throughout the study (Fig.1B). Leaf production for all growth types was strongly related to the shoot development rate, and the growth types responded similarly in this respect [leaf development (square centimeters per 14 days $)=5.66$ (number of shoots developed per 14 days $\left.)+3.58 ; r^{2}=0.71\right]$. The final, canopy leaf area was largest for ST (5.6 $\left.\mathrm{m}^{2}\right)$, intermediate for PI $\left(2.3 \mathrm{~m}^{2}\right)$, and smallest for DW $\left(0.9 \mathrm{~m}^{2}\right)$. The dwarf type had a larger leaf $\left(51.8 \mathrm{~cm}^{2}\right)$ than either ST $\left(38.0 \mathrm{~cm}^{2}\right)$ or PI $\left(31.8 \mathrm{~cm}^{2}\right)$; however, the specific leaf weight $\left(0.0072 \mathrm{~g} \cdot \mathrm{cm}^{-2}\right)$, leaf $\mathrm{N}$ level $(3.4 \%)$, and stomata density ( 227 per square millimeter) were similar among growth types.

Because the three peach growth types were grafted to a seedling Bailey rootstock, we tested the scion effect on root morphology. The three scion growth types had no effect on the xylem area percentage of the root cylinder (55\%), number of vessels per square millimeter (141), cross-sectional area of the largest xylem vessel $\left(4.9 \mu \mathrm{m}^{2}\right)$, specific root length of roots $<1 \mathrm{~mm}$ in diameter $\left(0.11 \mathrm{mg} \cdot \mathrm{cm}^{-1}\right)$, or rooting angle of the primary roots of the root system $\left(68^{\circ}\right)$.

Root length density (RLD) of fine roots in

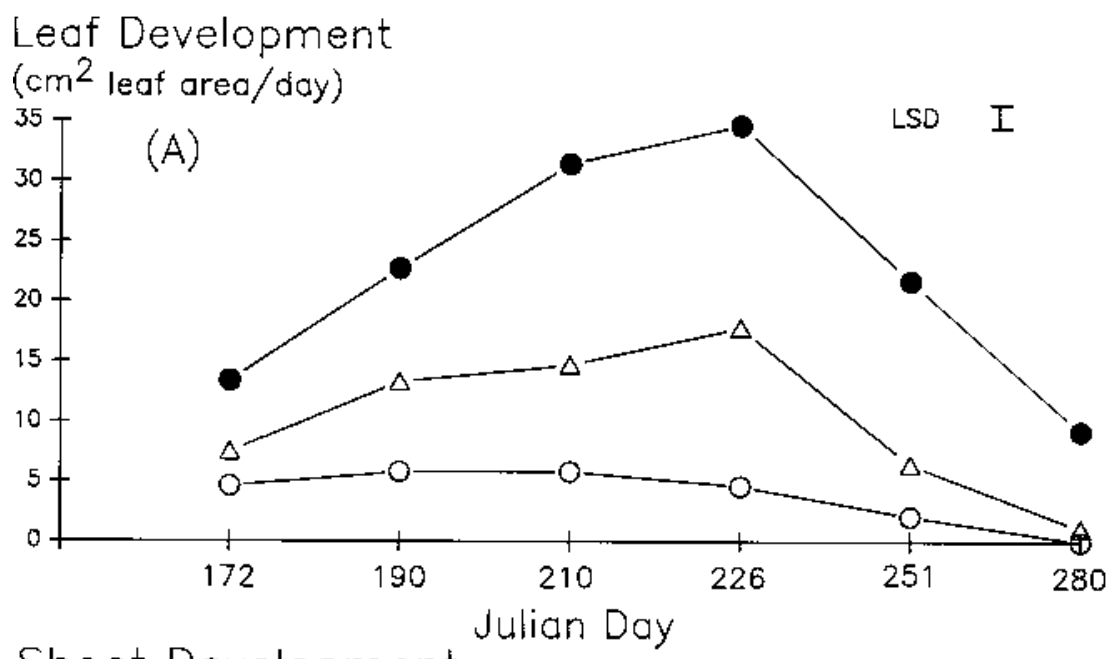

Shoot Development
(\# new shoots 14 days)

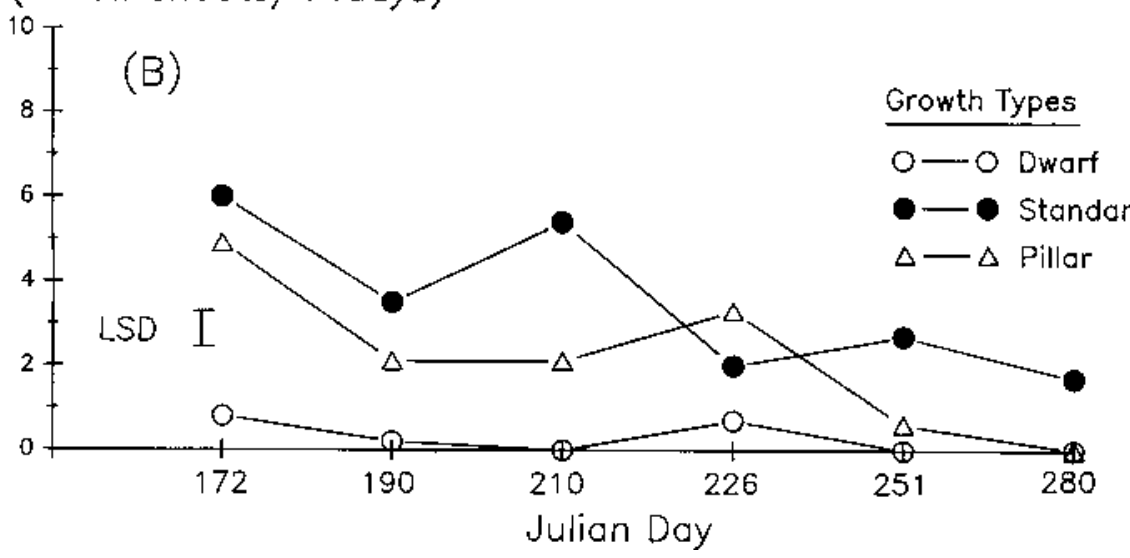

Fig. 1. Leaf and shoot development rates for three peach growth types least significant difference $(P \leq 0.05)$.
July was higher for ST and PI, which were similar, than for DW (Table 1). Large RLD in July was not affected by the scion. In September and October, fine RLD was in the following sequence: $\mathrm{ST}>\mathrm{PI}>\mathrm{DW}$. Large RLD for $\mathrm{ST}$ was greater than for PI or DW in September, but ST and PI had a higher RLD than DW in October.

The leaf : fine root ratio (L : FRR) represents the relationship between transpiration and water supply components of the plant. Dry matter distribution between leaves and fine roots (L : FRR) followed a consistent pattern for the three sampling dates of the study (data not shown). The pooled data show that, compared to PI, the rapidly growing ST partitioned more dry matter into leaves relative to that partitioned to fine roots; the slow-growing DW partitioned the least to leaves (Table1). Lehman et al. (1990) found that the most vigorous apple scion-rootstock combinations had the highest shoot : root dry matter ratio. Chandler (1934) also found that the percentage of peach root dry weight tended to decrease the faster the tree grew. In our study, L :FRR of all growth types increased from 8.4 in July to 12.8 in October $(P=0.05)$, indicating a change in this relationship during the growing season.

DeJong and Doyle (1984) and Glenn and Scorza (1992) found that DW peach trees had more dry-matter partitioning to leaves and less to wood than ST trees. We found similar results at the conclusion of our study (Table 1). The percentage of wood and large root tissue was higher and the percentage of fine root and leaf tissue was lower for ST and PI than for DW.

Reducing the size of peach trees through scion selection from ST or PI to DW resulted in less allocation of dry matter to large roots and woody tissue and more to leaf tissue, thus reducing the leaf : root mass ratio. Although these findings do not elucidate the physiological mechanism of growth habit modification, they do demonstrate that genetic differences in growth habit alter peach tree growth and structure. Genetically size-controlled peach trees have a smaller root system and a lower $\mathrm{L}$ : FRR than ST tree types. These may be selfcompensating characteristics in the water transport system of these trees. However, management of these smaller trees may require modifying irrigation and soil management techniques to ensure that the level of available soil water does not limit tree and fruit growth and development and that water and nutrient resources are not used inefficiently.

Table 1. Root length density and leaf, fine root, and dry matter distribution of three peach growth types.

\begin{tabular}{|c|c|c|c|c|c|c|c|c|c|c|c|}
\hline \multirow[b]{4}{*}{ Growth type } & \multicolumn{6}{|c|}{ Root length density ${ }^{2}$} & \multirow{4}{*}{$\begin{array}{c}\text { Leaf :fine root } \\
\text { ratio } \\
\left(\mathrm{g} \cdot \mathrm{g}^{-1}\right)\end{array}$} & \multirow{2}{*}{\multicolumn{4}{|c|}{$\begin{array}{c}\text { Dry-matter partitioning } \\
(\%)\end{array}$}} \\
\hline & \multirow{2}{*}{\multicolumn{3}{|c|}{$\begin{array}{l}\text { Fine roots } \\
\left(\mathrm{cm} \cdot \mathrm{cm}^{-3}\right)\end{array}$}} & \multirow{2}{*}{\multicolumn{3}{|c|}{$\begin{array}{c}\text { Large roots } \\
\left(\mathrm{cm} \cdot \mathrm{cm}^{-3} \times 1000\right)\end{array}$}} & & & & & \\
\hline & & & & & & & & Large & Fine & & \\
\hline & July & September & October & $\overline{\text { July }}$ & September & October & & root & root & Wood & Leaf \\
\hline Dwarf & $0.8 \mathrm{~B}^{\mathrm{y}}$ & $1.5 \mathrm{C}$ & $1.2 \mathrm{C}$ & 0.6 & $2.8 \mathrm{~B}$ & $10.8 \mathrm{~B}$ & $7.5 \mathrm{C}^{\mathrm{x}}$ & $13 \mathrm{~B}$ & $7 \mathrm{~A}$ & $19 \mathrm{~B}$ & $\overline{61 \mathrm{~A}}$ \\
\hline Pillar & $1.5 \mathrm{~A}$ & $2.4 \mathrm{~B}$ & $2.1 \mathrm{~B}$ & 2.0 & $8.3 \mathrm{~B}$ & $67.6 \mathrm{~A}$ & $11.0 \mathrm{~B}$ & $30 \mathrm{~A}$ & $2 \mathrm{~B}$ & $36 \mathrm{~A}$ & $32 \mathrm{~B}$ \\
\hline Standard & $1.4 \mathrm{~A}$ & $4.5 \mathrm{~A}$ & $5.7 \mathrm{~A}$ & 2.2 & $33.9 \mathrm{~A}$ & $89.2 \mathrm{~A}$ & $13.5 \mathrm{~A}$ & $34 \mathrm{~A}$ & $2 \mathrm{~B}$ & $38 \mathrm{~A}$ & $26 \mathrm{~B}$ \\
\hline
\end{tabular}

${ }^{2}$ Fine roots are $<1 \mathrm{~mm}$ in diameter, large roots are $>1 \mathrm{~mm}$ in diameter.

y Mean separation within columns using Gabriel-Rinot least significant range test $(P \leq 0.05)$.

${ }^{\mathrm{x}}$ Growth type $\times$ date of sampling interaction was not significant $(P=0.05)$; data are pooled over three sampling dates. 


\section{Literature Cited}

Cappellini, P., M.T. Dettori, and R. di Gaetano. 1992. The photosynthetic activity of different peach genotypes. XXIII Intl. Hort. Congr., Florence, Italy, 27 Aug.-1 Sept. 1990. (Abstr. 1814.)

Chandler, W.H. 1934. The dry-matter residue of trees and their products in proportion to leaf area. Proc. Amer. Soc. Hort. Sci. 31:39-56.

Cristoferi, G. and N. Filiti. 1981. Endogenous growth regulator levels in normal and dwarf peach cultivars. Riv. Ortoflorofrutt. It. 65:329-342.

DeJong, T.M. and J.F. Doyle. 1984. Cropping efficiency, dry matter and nitrogen distribution in mature genetic dwarf and standard peach trees. Acta Hort. 146:89-95.

Glenn, D.M. and R. Scorza. 1992. Reciprocal grafts of standard and dwarf peach alter dry-matter partitioning and root physiology. HortScience 27:241-243.
Glenn, D.M. and W.V. Welker. 1991. Soil management affects shoot and root growth, nutrient availability, and water uptake of young peach trees. J. Amer. Soc. Hort. Sci. 116:238-241.

Hansche, P.E. 1989. Three brachytic dwarf peach cultivars: Valley Gem, Valley Red, and Valley Sun. HortScience 24:707-709.

Hooper, J. 1867. The Italian dwarf peach. Amer. J. Hort. 2:287-288.

Lehman, L.J., E. Young, and C.R. Unrath. 1990. Growth dynamics of young apple trees as influenced by scion and rootstock vigor. J. Hort. Sci. 65:123-127.

Scorza, R. 1984. Characterization of four distinct peach tree growth types. J. Amer. Soc. Hort. Sci. 109:455-457.

Scorza, R. 1988. Progress in the development of new peach tree growth habits. Compact Fruit Tree 21:92-98.

Scorza, R. and J.M. Cordts. 1989. Differential sen- sitivity of 'CompactRedhaven' and 'Redhaven' peach shoot tips to BA in vitro. HortScience 24:334-336

Scorza, R., G.W. Lightner, and A. Liverani. 1989. The pillar peach tree and growth habit analysis of Compact x Pillar progeny. J. Amer. Soc. Hort. Sci. 114:991-995.

Smucker, A.J.M., S.L. McBurney, and A.K. Srivastava. 1982. Quantitative separation of roots from compacted soil profiles by the hydropneumatic elutriation system. Agron J. 74:500-503.

Strong, W.C. 1867. The Van Buren Golden Dwarf peach. Amer. J. Hort. Sci. 2:171-172.

Tennant, D. 1975. A test of a modified line intersect method of estimating root length. J.Ecol. 63:9951001.

Wylie, A. and K. Ryugo. 1971. Diffusable and extractable growth regulators in normal and dwarf shoot apices of peach, Prunus persica (L.) Batsch. Plant Physiol. 48:91-93. 